\title{
The Occurrence of Integrase Genes in Different Stages of Wastewater Treatment
}

\author{
Martyna Buta', Jakub Hubeny', Wiktor Zieliński', Ewa Korzeniewska', \\ Monika Harnisz', Monika Nowrotek², Grażyna Płaza² \\ 1 Department of Environmental Microbiology, Faculty of Environmental Sciences, University of Warmia and \\ Mazury, Prawocheńskiego 1, 10-720 Olsztyn, Poland \\ 2 Department of Environmental Microbiology, Institute for Ecology of Industrial Areas, Kossutha 6, \\ 40-844 Katowice, Poland \\ * Corresponding author's e-mail: martyna.buta@uwm.edu.pl
}

\begin{abstract}
The uncontrolled use of antibiotics and the release of drug residuals into the environment contribute to antibiotic resistance and constitute a serious public health threat. The spread of antibiotic resistance can be attributed mainly to the huge amounts of bacteria harboring the antibiotic resistance genes (ARGs) which are released into the environment with the treated wastewater. The molecular mechanisms of antibiotic resistance, in which the mobile genetic elements (MGEs) such as plasmids, transposons, bacteriophages and integrons associated with the transfer of ARGs play the main role, should be broadly investigated to develop effective methods for addressing this problem. This study focused mainly on integrons which: (i) are the simple elements involved in the mobility of gene cassettes, (ii) have a common structure, (iii) can be associated with other MGEs, and (iv) are particularly efficient in trapping ARGs. The aim of the study was to estimate the efficiency of different stages of the wastewater treatment process in removing class 1, 2 and 3 integrase genes in two wastewater treatment plants (WWTPs) in Poland and to investigate the presence of these genes in river water upstream and downstream from the effluent discharge point. The presence of int 11 , int 12 and int 13 genes was analysed by means of standard PCR with specific primers and a thermal cycling profiles. The samples of wastewater and sludge were collected from two WWTPs located in the Polish regions of (a) Warmia and Mazury, and (b) Silesia. The samples of river water were also collected upstream and downstream from the examined WWTPs. In the selected WWTPs, wastewater is treated through the activated sludge process with various modifications. The presence of int $\mathrm{I} 1$, int $\mathrm{I} 2$ and int $\mathrm{I} 3$ genes in different stages of wastewater treatment was characterized by a similar pattern. The results of this study indicate that WWTPs are not highly effective in removing the integrase genes from all three integron classes. The study revealed somewhat unexpected results, which indicate that the recently discontinued monitoring of the int 13 gene in the wastewater treatment process should be reinstated. The existing wastewater treatment systems should be improved and modified to effectively eliminate the integrase genes from wastewater and prevent contamination of the surface water.
\end{abstract}

Keywords: integrase, integron, ARGs, wastewater

\section{INTRODUCTION}

Nowadays, antibiotic resistance is a global health issue in which the main role is played by the antibiotic resistant bacteria (ARB) that carry and transfer the antibiotic resistance genes (ARGs) into the environment [Pruden et al. 2013, Narciso-da-Rocha and Manaia 2016]. Antibiotic resistance is caused not only by the persistence of the naturally occurring ARGs in bacteria or the evolution of ARGs in the bacterial communities colonizing the habitats characterized by high amounts of antibiotics and their transformation products (TPs) [Osińska et al., 2017a]. The spread of ARGs by horizontal gene transfer (HGT) and the rate at which this process occurs give a much greater cause for concern. Mobile genetic elements (MGEs) such as integrons, plasmids, 
transposons, insertion sequences and genomic islands play an important role in incorporating new genes into the bacterial genome [Lekunberri et al., 2018]. Moreover, the widespread problem of antibiotic resistance is favored by the aquatic environment as a main pathway of pollutants spreading. Wastewater treatment plants (WWTPs) play an important role in this process as a major source of organic compounds and nutrients for bacterial proliferation [Makowska et al., 2016]. Raw wastewater contains carbon compounds as well as sub-inhibitory concentrations of antibiotics and other antimicrobials [Giebułtowicz et al., 2018] which promote the bacterial adaptation and contribute to the development of highly resistant bacteria [Rizzo et al., 2013]. High bacterial loads and the specificity of WWTPs promote the contact and gene transfer between microbial species or genera and between bacteria and the environment [Karkman et al., 2018]. The treated wastewater containing dangerous bacteria is often discharged to rivers, from where the antibiotic resistance determinants and ARB are transferred to other water bodies and environments, thus posing a considerable health risk for humans and animals [Paiva et al., 2015, Subirats et al., 2018].

Modern WWTPs deploy various wastewater treatment methods, including mechanical, biological and mechanical-biological methods with elevated removal of nutrients, sequencing batch reactors (SBR) or anaerobic/anoxic/oxic (A2 / O) systems [Korzeniewska and Harnisz 2018]. According to Rizzo et al. [2013], the biological treatment systems, where wastewater is continuously mixed, could be responsible for faster distribution of new genes. New treatment methods capable of removing a substantial percentage of pharmaceuticals from the treated wastewater have been developed over the past 20 years. However, these methods are very expensive, and there is still a demand for effective and low-cost treatment systems [Berglund et al. 2014]. Until such methods are deployed in WWTPs, highly virulent microorganisms will continue to be discharged with treated wastewater into the environment.

The essence of spreading antibiotic resistance in the environment should be sought in its molecular foundations. In this study, special attention was paid to integrons which are linked to MGEs. Integrons have been detected in the DNA of commensal and pathogenic bacteria colonizing humans and animals [Paiva et al., 2015]. Integrons used to be called a critical intermediate in the capturing and expression process of resistance genes [Giebułtowicz et al., 2018]. They are able to build specific gene cassettes that carry ARGs, metal resistance genes, protein transport determinants and other proteins with unknown features into bacterial genome [Koczura et al., 2016]. In the group of the identified HGT mechanisms, conjugation significantly simplifies the transfer of integrons between bacteria via plasmids or transposons [Giebultowicz et al., 2018]. Due to their specific abilities, integrons are used as indicators to determine the distribution patterns of different resistance genes in the bacterial population [Le et al., 2016].

The objective of this study was to estimate the efficiency of particular steps of the treatment process in removing the integron-integrase genes class 1, 2 and 3 in two WWTPs and to determine the distribution pattern of the integrase genes in the samples of river water and wastewater collected in different stages of the treatment process in summer and autumn. An attempt to estimate seasonal fluctuations in the content of intiI1, int 2 and $\operatorname{int} \mathrm{I} 3$ genes in wastewater was made as well.

\section{MATERIAL AND METHODS}

\section{Characterization of WWTPs and samples collection}

The study was conducted in two WWTPs located in the Polish regions of (a) Warmia and Mazury, and (b) Silesia. In the examined WWTPs, wastewater is treated through the activated sludge process with various modifications: (a) mechanical-biological methods with an elevated removal of nutrients (b) mechanical-biological treatment methods with sequencing batch reactor technology (C-TECH) (Table 1). The samples of wastewater, river water and sludge were collected in sterile bottles and urine containers, respectively, and they were transported to the laboratory under refrigerated conditions $\left(4^{\circ} \mathrm{C}\right)$.

\section{Samples preparation and genomic DNA extraction}

Specific amounts (Table 2) of the collected water and wastewater samples were passed through polycarbonate filters with $0.2 \mu \mathrm{m}$ porosity (Merck, Millipore). The filters were transferred to sterile Falcon tubes for DNA extraction. The 
Table 1. Characteristic of examined WWTPs

\begin{tabular}{|c|c|c|c|}
\hline $\begin{array}{c}\text { Location of wastewater } \\
\text { treatment plant }\end{array}$ & $\begin{array}{c}\text { Type of wastewater treatment } \\
\text { system }\end{array}$ & Type of inflowing wastewater & $\begin{array}{c}\text { Average processing } \\
\text { capacity }\left(\mathrm{m}^{3} / \mathrm{d}\right)\end{array}$ \\
\hline Warmia and Mazury District & $\begin{array}{c}\text { Mechanical-biological method } \\
\text { with elevated removal of } \\
\text { nutrients }\end{array}$ & $\begin{array}{c}\text { Domestic sewage, hospital } \\
\text { sewage, food industry sewage }\end{array}$ & 35,000 \\
\hline Silesian District & $\begin{array}{c}\text { Mechanical-biological method } \\
\text { with sequencing C - TECH } \\
\text { reactors }\end{array}$ & $\begin{array}{c}\text { Domestic sewage, industry } \\
\text { sewage }\end{array}$ & 30,000 \\
\hline
\end{tabular}

genomic DNA from water and wastewater samples was extracted with the DNeasy Power Water Kit (Qiagen). In order to obtain gDNA from sediments, $0.25 \mathrm{~g}$ of each sample was weighed and isolated with the DNeasy Power Soil Kit (Qiagen) according to the manufacturer's protocol. The quality and concentration of the extracted DNA were measured with the Multiskan Sky Microplate Spectrophotometer (Thermo Scientific). All extracted gDNA samples were stored at $-20^{\circ} \mathrm{C}$.

\section{Detection of the integron - integrase genes by standard PCR}

The class 1 (int $\mathrm{I} 1), 2(\operatorname{int} \mathrm{I} 2)$ and 3 (int $\mathrm{I} 3)$ integron-integrase genes were identified molecularly with standard PCR. The single PCR mixture of $20 \mu$ contained the NZY Taq II 2x Green Master Mix, the DNA template and specific primers recommended by Goldstein (2001) and Dillon
(2005). Primer sequences and annealing temperature are given in Table 3. After the amplification of specific DNA fragments, all samples were visualized through electrophoresis in $1.5 \%$ agarose gel which was prepared by suspending agarose in $1 \mathrm{X}$ TBE (Tris - Borate - EDTA) buffer and ethidium bromide staining $(0.5 \mu \mathrm{g} / \mathrm{mL})$. Electrophoresis was conducted at $120 \mathrm{~V} / 10 \mathrm{~min}$ and $80 \mathrm{~V} / 60 \mathrm{~min}$

\section{RESULTS AND DISCUSSION}

Despite the fact that more than $99 \%$ of microorganisms are eliminated from wastewater during the technological processes in WWTPs [Osińska et al. 2017b, Korzeniewska and Harnisz 2018], alarming amounts of pathogenic bacteria are discharged to rivers and other water bodies with treated effluents [Ben et al.

Table 2. Type of collected samples and filtered amount

\begin{tabular}{|c|c|c|c|}
\hline \multirow[t]{2}{*}{ Type of sample } & \multirow[t]{2}{*}{ Place of sampling } & \multicolumn{2}{|c|}{$\begin{array}{l}\text { Amount of filtered sample } \\
(\mathrm{mL}) / \text { sample weight }(\mathrm{g})\end{array}$} \\
\hline & & Summer & Autumn \\
\hline Untreated wastewater & \multirow{9}{*}{$\begin{array}{l}\text { WWTP in Warmia } \\
\text { and Mazury District }\end{array}$} & 40 & 40 \\
\hline Wastewater after the primary settling tank & & 40 & 40 \\
\hline Wastewater after the biological chamber & & 40 & 20 \\
\hline Wastewater after the multi - functional reactor & & 40 & 40 \\
\hline Treated wastewater & & 200 & 200 \\
\hline Sample from collector before the discharge of treated wastewater & & 200 & 400 \\
\hline Sample from collector after the discharge of treated wastewater & & 200 & 400 \\
\hline Sludge from the open fermentation pool & & 0.25 & 0.25 \\
\hline Sludge ready to development & & 0.25 & 0.25 \\
\hline Untreated wastewater & \multirow{10}{*}{ WWTP in Silesian District } & 10 & 40 \\
\hline Wastewater after the primary settling tank & & 30 & 30 \\
\hline Wastewater after the secondary settling tank & & 200 & 300 \\
\hline Wastewater after the selector and $\mathrm{C}-\mathrm{TECH}$ reactor & & 150 & 300 \\
\hline Treated wastewater & & 150 & 300 \\
\hline Sample from collector before the discharge of treated wastewater & & 150 & 300 \\
\hline Sample from collector after the discharge of treated wastewater & & 150 & 300 \\
\hline Suspension outflowing after the dewatering process & & 10 & 30 \\
\hline Sludge after the mechanical compression & & 0.25 & 0.25 \\
\hline Sludge after the gravity compression & & 0.25 & 0.25 \\
\hline
\end{tabular}


Table 3. Primer sequences and conditions of PCR.

\begin{tabular}{|c|c|c|c|c|}
\hline Gene name & Primer sequence & $\begin{array}{c}\text { Amplicon size } \\
{[\mathrm{bp}]}\end{array}$ & $\begin{array}{c}\text { Annealing } \\
\text { temperature }\left[{ }^{\circ} \mathrm{C}\right]\end{array}$ & Reference \\
\hline \multirow{2}{*}{ intl1 } & CCTCCCGCACGATGATC & \multirow{2}{*}{280} & \multirow{2}{*}{55} & \multirow{4}{*}{ Goldstein 2001} \\
\hline & TCCACGCATCGTCAGGC & & & \\
\hline \multirow{2}{*}{ int 12} & TTATTGCTGGGATTAGGC & \multirow{2}{*}{233} & \multirow{2}{*}{50} & \\
\hline & ACGGCTACCCTCTGTTATC & & & \\
\hline \multirow{2}{*}{ int 13} & GCCTCCGGCAGCGACTTTCAG & \multirow{2}{*}{979} & \multirow{2}{*}{59} & \multirow{2}{*}{ Dillon et al. 2005} \\
\hline & ACGGATCTGCCAAACCTGACT & & & \\
\hline
\end{tabular}

2017, Munir et al. 2011]. Wastewater treatment plants are a specific highway to the rapid spread of antibiotic resistance by promoting the bacterial contact and enabling microorganisms to incorporate new genes into their genome as well as transport these genes to other bacteria through the HGT mechanism [Gatica et al. 2016, Guo et al. 2017]. The process of capturing and incorporating virulence genes would not be as effective without integrative and conjugative elements (ICEs) [Beceiro et al. 2013]. Integrons play an indisputable role in the spread of antibiotic resistance [Laroche et al. 2009], which is why many studies have investigated the presence of the integrase gene, an element responsible for catalyzing the recombination between the incorporated gene cassettes and the recombination site (attI) [Gillings 2014, Deng et al. 2015].

In this study, the class 1, 2 and 3 integronintegrase genes were detected in different stages of wastewater treatment. The class 1 integronintegrase genes were not effectively removed with the mechanical-biological methods with an elevated removal of nutrients in the WWTP in Warmia and Mazury or by means of the mechanical-biological methods with C-TECH reactors in the WWTP in Silesia (Tables 4 and 5). The removal efficiency of the bacteria carrying int $\mathrm{I} 1$ genes was also low in the WWTPs investigated by Du et al. [2015] and Li et al. [2014]. The class 1 integrons are found mainly in Gram-negative bacteria such as Acinetobacter, Alcaligenes, Citrobacter, Enterobacter, Escherichia, Klebsiella, Pseudomonas, Salmonella, Shigella, Staphylococcus [Deng et al. 2015, Xu et al. 2011], some of which are common pathogens that cause numerous infections [Kaushik et al. 2019]. For this reason, the class 1 integron-integrase genes are often identified in WWTPs that process hospital wastewater. The previous studies have demonstrated that WWTPs act as hotspots for the spread of the pathogenic and antibiotic-resistant bacteria, as well as that the released microorganisms and the carried genes can contribute to the spread of virulence in the environment [Calhau et al. 2015, Osińska et al. 2017b].

According to some authors, the class 2 integrons are less common than the class 1 integrons [Deng et al. 2015, Barlow and Gobius 2006]. In the present study, int $\mathrm{I} 2$ were almost as prevalent as int I1 in both WWTPs. Class 2 integrase is characteristic of the bacteria that colonize the human and animal feces (e.g. E. coli and E. faecalis); therefore, int $\mathrm{I} 2$ is abundant in wastewater [Uyaguari et al. 2013]. It is also frequently carried by the bacteria of the Acinetobacter, Salmonella and Pseudomonas genera. The presence of the class 2 integron genes in the treated wastewater discharged into a river is highly alarming. In a study by Korzeniewska and Harnisz (2018), the percentage of ARB in total bacterial counts was much higher in the samples of treated wastewater than raw wastewater.

During the wastewater monitoring in WWTPs, the main emphasis is placed on the class 1 and 2 integrons. The class 3 integrons are far less prevalent, and they are monitored less frequently. However, Stadler et al. (2014) reported that the int $\mathrm{I} 3$ gene was more abundant than the int $\mathrm{I} 2$ gene in the wastewater samples collected from a WWTP. According to Uyaguari et al. (2013), the class 3 integrons are much more widespread in the environment than previously thought. Similar observations were made in the current study where in $\mathrm{t} 3$ was present in the wastewater and sludge samples collected from both WWTPs. These results indicate that the monitoring of the int $\mathrm{I} 3$ gene in the discharged effluents should be reinstated in WWTPs. Some authors also reported the presence of the class 1, 2 and 3 integrons in the untreated wastewater, in the wastewater samples collected in different stages of treatment, as well as in the treated wastewater [Moura et al. 2010, Uyaguari et al. 2013]. 
Table 4. Presence of the class 1-3 integrase genes in the samples from WWTP in the Warmia and Mazury District.

\begin{tabular}{|c|c|c|c|c|}
\hline \multirow{2}{*}{ Type of sample } & \multirow{2}{*}{ Season of sampling } & \multicolumn{3}{|c|}{ Presence of genes } \\
\hline & & intl1 & int 12 & int 13 \\
\hline Untreated wastewater & \multirow{9}{*}{ Summer } & + & + & + \\
\hline Wastewater after the primary settling tank & & + & + & + \\
\hline Wastewater after the biological chamber & & + & + & - \\
\hline Wastewater after the multi - functional reactor & & + & + & + \\
\hline Treated wastewater & & + & + & + \\
\hline Sample from collector before the discharge of treated wastewater & & + & - & + \\
\hline Sample from collector after the discharge of treated wastewater & & + & + & + \\
\hline Sludge from the open fermentation pool & & + & + & + \\
\hline Sludge ready to development & & + & + & + \\
\hline Untreated wastewater & \multirow{9}{*}{ Autumn } & + & + & + \\
\hline Wastewater after the primary settling tank & & + & + & + \\
\hline Wastewater after the biological chamber & & + & + & + \\
\hline Wastewater after the multi - functional reactor & & + & + & + \\
\hline Treated wastewater & & + & + & + \\
\hline Sample from collector before the discharge of treated wastewater & & + & - & + \\
\hline Sample from collector after the discharge of treated wastewater & & + & + & + \\
\hline Sludge from the open fermentation pool & & + & + & + \\
\hline Sludge ready to development & & + & + & + \\
\hline
\end{tabular}

Table 5. Presence of the class 1-3 integrase genes in the samples from WWTP in the Silesian District

\begin{tabular}{|c|c|c|c|c|}
\hline \multirow{2}{*}{ Type of sample } & \multirow{2}{*}{ Season of sampling } & \multicolumn{3}{|c|}{ Presence of genes } \\
\hline & & intl1 & intl2 & intl3 \\
\hline Untreated wastewater & \multirow{10}{*}{ Summer } & + & + & + \\
\hline Wastewater after the primary settling tank & & + & + & + \\
\hline Wastewater after the secondary settling tank & & + & + & + \\
\hline Wastewater after the selector and $\mathrm{C}-\mathrm{TECH}$ reactor & & + & + & + \\
\hline Treated wastewater & & + & + & + \\
\hline Sample from the collector before the discharge of treated wastewater & & + & + & + \\
\hline Sample from the collector after the discharge of treated wastewater & & + & + & + \\
\hline Suspension outflowing after the dewatering process & & + & + & + \\
\hline Sludge after the mechanical compression & & + & + & + \\
\hline Sludge after the gravity compression & & + & + & + \\
\hline Untreated wastewater & \multirow{10}{*}{ Autumn } & + & + & + \\
\hline Wastewater after the primary settling tank & & + & + & + \\
\hline Wastewater after the secondary settling tank & & + & + & + \\
\hline Wastewater after the selector and $\mathrm{C}-\mathrm{TECH}$ reactor & & + & + & + \\
\hline Treated wastewater & & + & + & + \\
\hline Sample from the collector before the discharge of treated wastewater & & + & + & + \\
\hline Sample from the collector after the discharge of treated wastewater & & + & + & + \\
\hline Suspension outflowing after the dewatering process & & + & + & + \\
\hline Sludge after the mechanical compression & & + & + & + \\
\hline Sludge after the gravity compression & & + & + & + \\
\hline
\end{tabular}

The results of this study indicate that the microbiological quality of the wastewater discharged to the surface waters is a serious concern that poses a considerable threat for the human and animal health. Further research to develop new wastewater treatment methods or modify and combine the existing technologies to effectively reduce ARGs in the effluents discharged from WWTPs is recommended. 


\section{CONCLUSION}

Different types of wastewater that are treated in WWTPs with the use of various processing methods continue to pose a threat to humans and the environment. The treated wastewater containing significant amounts of potentially pathogenic microorganisms carrying the integrase genes may contribute to the growing levels of antibiotic resistance. The transmission of integrase genes between microorganisms during different stages of the wastewater treatment process may enhance the above-mentioned risk. Further work is recommended to modify the existing methods of wastewater treatment with a view to minimize the contamination of partially treated wastewater and reduce bacterial counts in the effluents discharged to the surface waters.

\section{Acknowledgements}

This study was supported by grant No. POWR.03.02.00-00-I034/16-00 from the European Social Fund and grants No. 2017/27/B/ NZ9/00267 and 2017/26/M/NZ9/0007 from the National Science Centre (Poland).

\section{REFERENCES}

1. Barlow R.S., Gobius K.S. 2006. Diverse class 2 integrons in bacteria from beef cattle sources. Journal of Antimicrobial Chemotherapy 58(6), 1133-1138.

2. Beceiro A., Tomás M., Bou G. 2013. Antimicrobial Resistance and virulence: a successful or deleterious association in the bacterial world. Clin Microbiol Rev. 26(2), 185-230.

3. Ben W., Wang J., Cao R., Yang M., Zhang Y., Qiang Z. 2017. Distribution of antibiotic resistance in the effluents of ten municipal wastewater treatment plants in China and the effect of treatment processes. Chemosphere 172, 392-398.

4. Berglund B., Ghazanfar A.K., Weisner S.E.B., Ehde P.M., Fick J., Lindgren P.E. 2014. Efficient removal of antibiotics in surface-flow constructed wetlands, with no observed impact on antibiotic resistance genes. Science of the Total Environment 476, 29-37.

5. Calhau V., Mendes C., Pena A., Mendonça N., Da Silva G.J. 2015. Virulence and plasmidic resistance determinants of Escherichia coli isolated from municipal and hospital wastewater treatment plants. J Water Health. 13(2), 311-318

6. Deng Y., Bao X., Ji L., Chen L., Liu Y., Miao J., Chen D., Bian H., Li Y., Yu G. 2015. Resistance integrons: class 1, 2 and 3 integrons. Annals of Clinical Microbiology and Antimicrobials 14(1), 45.

7. Dillon B., Thomas L., Mohmand G., Zelynski A., Iredell J. 2005. Multiplex PCR for screening of integrons in bacterial lysates. Journal of Microbiological Methods 62(2), 221-232.

8. Du J., Geng J., Ren H., Ding L., Xu K., Zhang Y. 2015. Variation of antibiotic resistance genes in municipal wastewater treatment plant with A 2 OMBR system. Environmental Science and Pollution Research 22(5), 3715-3726.

9. Gatica J, Tripathi V., Green S., Manaia C.M., Berendonk T., Cacace D., Merlin C.,Kreuzinger N.,Schwartz T., Fatta-Kassinos D., Rizzo L., Schwermer C.U., Garelick H., Jurkevitch, Cytryn E. 2016. High throughput analysis of integron gene cassettes in wastewater environments. Environmental Science \& Technology 50(21), 11825-11836.

10. Giebułtowicz J., Tyski S., Wolinowska R., Grzybowska W., Zaręba T., Drobniewska A., Wroczyński P., Nałęcz-Jawecki G. 2018. Occurrence of antimicrobial agents, drug-resistant bacteria, and genes in the sewage-impacted Vistula River (Poland). Environmental Science and Pollution Research 25(6), 5788-5807.

11. Gillings M.R. 2014. Integrons: past, present, and future. Microbiology and Molecular Biology Reviews. 78(2), 257-277.

12. Goldstein C., Lee M.D., Sanchez S., Chudson C., Phillips B., Register B., Grady M., Libert C., Summers A.O., White D.G., Mauer J.J. 2001. Incidence of Class 1 and 2 Integrases in Clinical and Commensal Bacteria from Livestock, Companion Animals, and Exotics. Antimicrob Agents Ch. 45(3), 723-726.

13. Karkman A., Do T.T., Walsh F., Virta M.P.J. 2018. Antibiotic-resistance genes in waste water. Trends in Microbiology 26(3): 220-228.

14. Kaushik M., Kumar S., Kapoor R.Kr., Gulati P. 2019. Integrons and antibiotic resistance genes in water-borne pathogens: threat detection and risk assessment. Journal of Medical Microbiology 68(5), 679-692.

15. Koczura R., Mokracka J., Taraszewska A., Łopacinska N. 2016. Abundance of class 1 integronintegrase and sulfonamide resistance genes in river water and sediment is affected by anthropogenic pressure and environmental factors. Microbial Ecology 72(4), 909-916.

16. Korzeniewska E., Harnisz M. 2018. Relationship between modification of activated sludge wastewater treatment and changes in antibiotic resistance of bacteria. Science of the Total Environment 639, 304-315.

17. Laroche E., Pawlak B., Berthe T., Skurnik D., Petit F. 2009 Occurrence of antibiotic resistance and class 1,2 and 3 integrons in Escherichia coli isolated from 
a densely populated estuary (Seine, France). FEMS microbiology ecology 68(1), 118-130.

18. Lekunberri I., Balcázar J.I, Borrego C.M. Metagenomic exploration reveals a marked change in the river resistome and mobilome after treated wastewater discharges. Environmental Pollution 234: 538-542.

19. Li J., Cheng W., Xu L., Strong P.J., Chen H. 2015. Antibiotic-resistant genes and antibiotic-resistant bacteria in the effluent of urban residential areas, hospitals, and a municipal wastewater treatment plant system. Environmental Science and Pollution Research 22(6), 4587-4596.

20. Makowska N., Koczura R., Mokracka J. 2016. Class 1 integrase, sulfonamide and tetracycline resistance genes in wastewater treatment plant and surface water. Chemosphere 144, 1665-1673.

21. Moura A., Henriques I., Smalla K., Correia A. 2010. Wastewater bacterial communities bring together broad-host range plasmids, integrons and a wide diversity of uncharacterized gene cassettes. Research in Microbiology 161(1), 58-66.

22. Munir M., Wong K., Xagoraraki I. 2011. Release of antibiotic resistant bacteria and genes in the effluent and biosolids of five wastewater utilities in Michigan. Water Research 45(2), 681-693.

23. Narciso-da-Rocha C., Manaia C.M. 2017. The influence of the autochthonous wastewater microbiota and gene host on the fate of invasive antibiotic resistance genes. Science of the Total Environment $575,932-940$.

24. Osińska A., Korzeniewska E., Harnisz M., Niestępski S. 2017a. The prevalence and characterization of antibiotic-resistant and virulent Escherichia coli strains in the municipal wastewater system and their environmental fate. Science of the Total Environment. 577, 367-375.

25. Osińska A., Korzeniewska E., Harnisz M., Niestępski S. 2017b. Impact of type of wastewater treatment process on the antibiotic resistance of bacterial populations. In E3S Web of Conferences (Vol. 17, p. 00070). EDP Sciences.

26. Paiva M.C., Ávila M.P., Reis M.P., Costa P.S., Nardi R.M.D., Nascimento A.M.A. 2015. The microbiota and abundance of the class 1 integron-integrase gene in tropical sewage treatment plant influent and activated sludge. PloS one 10(6), e0131532.

27. Pruden A., Larsson D.J., Amézquita A., Collignon P., Brandt K.K., Graham D.W., Lazorcha J.M., Suzuki S., Silley P., Snape J.R., Topp E. 2013. Management options for reducing the release of antibiotics and antibiotic resistance genes to the environment. Environmental Health Perspectives, 121(8), 878-885.

28. Rizzo L., Manaia C., Merlin C., Schwartz T., Dagot C., Ploy M.C., Michael I., Fatta-Kassinos D. 2013. Urban wastewater treatment plants as hotspots for antibiotic resistant bacteria and genes spread into the environment: a review. Science of the Total Environment 447, 345-360.

29. Stalder T., Barraud O., Jové T., Casellas M., Gaschet M., Dagot C., Ploy M.C. 2014 Quantitative and qualitative impact of hospital effluent on dissemination of the integron pool. The ISME journal 8(4), 768.

30. Subirats J., Xisca T., Sànchez-Melsió A., Balcázar J.A., Acuña V., Sabater S., Borrego C.M. 2018. Emerging contaminants and nutrients synergistically affect the spread of class 1 integron-integrase (intI1) and sul1 genes within stable streambed bacterial communities. Water Research 138, 77-85.

31. Uyaguari M.I., Scott G.I., Norman R.S. 2013. Abundance of class 1-3 integrons in South Carolina estuarine ecosystems under high and low levels of anthropogenic influence. Marine Pollution Bulletin 76(1-2), 77-84.

32. Xu Z., Li L., Shi L., Shirtliff M.E. 2011. Class 1 integron in staphylococci. Molecular Biology Reports 38(8), 5261-5279. 